Europe's Journal of Psychology 2/2010, pp. 85-104

www.ejop.org

\title{
Dimensions of students' psychosocial well-being and their measurement: Validation of a students' Psychosocial Well Being Inventory
}

\author{
Valeria Negovan \\ University of Bucharest, Faculty of Psychology and Educational Sciences
}

\begin{abstract}
This paper presents findings from a validation study of a measurement instrument for the dimensions of students' psychosocial well-being. Researches to date suggest many separate but related dimensions of psychosocial well-being. In the current study, psychosocial well-being is considered to have four dimensions: subjective well-being related to every day's events, subjective well-being related to faculty events, psychological well-being and social well-being. Diener's (1985) and Seligman's (2002) models of subjective well-being and Ryff's (1995) and Keyes' (1998) models of psychological and social well-being served as the conceptual basis for the development of this instrument. The sample for the validation study consisted of 449 university students at the Faculty of Psychology and Educational Sciences, University of Bucharest, Romania. Participants completed seven self-report questionnaires that related to the individual's positive functioning in personal life and in society, including the Psychosocial Well Being Inventory (PSWBI). The validation study consisted of establishing the psychometric properties, factorial structure of the construct, and convergent and divergent validity of the instrument. Results show that PSWBI is a valid instrument, performing at least as well as popular measures of overall well-being but also specifying its dimensions.
\end{abstract}

Keywords: psychosocial well-being, subjective well-being, psychological well-being, social well-being, university student.

\section{Conceptual framework}

Life in the university environment presents many social - emotional challenges that can impact on students' well-being. 
Universities should assume their responsibility not only for the students' formal education, but also for their development in all its forms and especially in what quality of life and well-being are concerned. University students do not make efforts only to obtain good grades at the university, but also to live a good life. It is important to know that university students are constantly facing the risk of poor academic achievement or impaired social functioning in the context of their developmental and of broader social changes, of financial and accommodation problems, and also due to the specific demands of the academia (Misra \& McKean, 2000; Ross, Cleland, Macleod, 2006; Verger, et al. 2009). But it's also important to know how much satisfaction, happiness and other characteristics of good life students are experiencing in the university environment. To know that the university students are not satisfied, are not feel good about themselves and their social world, has the same importance as knowing that they are stressed or at risk (Haynes, 2002; Cicognani et al., 2008; Sheu Hung-Bin et al., 2009).

The study of well-being has been divided into two streams of research, respectively: the hedonic approach and the eudaimonic approach. The hedonic approach conceptualizes and defines well-being in terms of happiness and of the presence of pleasure and absence of pain and is reflected in the stream of research on subjective well-being (Bradburn, 1969; Diener, 1984; Diener et al., 1984). The eudaimonic approach equates well-being with human potential that, when realized, results in a person's optimal functioning in life (Diener, 1985; Ryan \& Deci, $2001 \mathrm{~b})$ and is reflected in the stream of research on psychological (Ryff, 1989) and social (Keyes, 1998) well-being.

One goal of researchers who studied well-being was to define the key features of the well-being construct (Kozma et al., 1991; Kafka \& Kozma, 2002) and one issue that they have analyzed was the number of dimensions or components that are needed to characterize people's positive evaluations of their lives.

Contemporary literature seems to agree with the idea that well-being is a multidimensional construct encompassing up to three dimensions: subjective, psychological and social; these dimensions are in fact differentiating three forms or levels of overall well-being. Each of these dimensions is described as multidimensional as well. However, when it comes to the sub-facets of the three principal components of overall well-being, researchers are still engaged in challenging debates.

In a valuable review of the literature on subjective well-being, Diener, Lucas, and Osihi (2005) refer to subjective well-being "as a person's cognitive and affective 
evaluations of his or her life" (p.63). Despite the lack of agreement about the number of dimensions contained by subjective well-being, two main components are generally recognized: a cognitive (satisfaction) and an affective (pleasant affect, and low levels of unpleasant affect) component (Bradburn, 1969; Andrews and Withey, 1976; Diener, 1984; Diener et al., 1985). Other theorists proposed additional conceptual models for understanding subjective well-being. Martin E. P. Seligman (2000) has distinguished between feelings of meaning, pleasure (including happy emotions), and engagement (interest and "flow") and approached subjective well-being in terms of happiness, identifying the following substructure of happiness: "1. pleasure (or positive emotion); 2. engagement; 3. meaning" (Seligman, Parks, Steen, 2005, p.275). In Csikszentmihalyi's model, subjective wellbeing depends on being involved in interesting activities. Interesting activities are those in which there is an optimal balance between challenge and skill (Csikszentmihalyi, 1975, 1990).

Many psychologists who conducted empirical research on well-being based on the eudaimonic approach of the good life, argued that living well is not simply a matter of experiencing more pleasure than pain; instead, it involves a striving for perfection and realization of one's true potential (Ryff, 1989). Ryff and Singer (2005) affirmed that subjective well-being is a fallible indicator of wellness that was not designed to define the basic structure of psychological well-being.

Ryff (1989) proposed the concept of psychological well-being as a multidimensional construct that consists of six distinct facets: a) positive attitude toward oneself (selfacceptance); b) satisfying relationships with others (positive relationships with others); c) independence and self-determination (autonomy); d) sense of mastery and competence (environmental mastery); e) sense of goal directedness in life (purpose in life); f) feeling of personal continued development (personal growth).

A more socially-oriented definition of well-being has been proposed by Keyes (1998). In his opinion social well-being captures individuals' appraisals of their own circumstances and functioning in society. Social well-being is considered an important component of overall well-being, in addition to the emotional and psychological types of well-being (Keyes, 2003). Keyes' (1998) multidimensional model of social well-being consists of five dimensions that indicate whether and to what extent individuals are functioning well in their social world: a) social integration (individuals' appraisal of the quality of their own relation with society and community); b) social contribution (the feeling of being a vital member of the society, with something important to offer to the world); c) social acceptance (trusting others, and having favourable opinions about human nature); d) social 
actualization (the evaluation of a society's potential to improve); e) social coherence (the perception of that the social word is well-organized).

The term psychosocial well-being is used nowadays in the literature to refer to a wide range of issues including, but not limited to, mental, emotional, social, physical, economic, cultural, and spiritual health and, consequently, it has been defined in numerous ways. It is agreed that a model of psychosocial well-being should include and reflect the interconnectedness of the various aspects of overall well-being (Linley, et al., 2009).

The multidimensionality of the well-being construct posed many methodological problems when researchers attempted to measure it.

Subjective well-being is most commonly measured by asking people a single question, such as "how satisfied are you with your life as a whole (these days or past month)?". Such question elicits a global evaluation of one's life (Andrews and Whithey, 1976). In contrast to single question measures, multi-item measures of subjective well-being were developed with the purposes to achieving greater reliability. Life satisfaction scales or Affect scales are such multi-items measures of subjective well-being (Diener et al., 1985; Kozma and Stones, 1980; Pavrot and Diener, 1993). Multi-item measures have also been developed for psychological and social well-being. For example, Ryff (1989) created the Scales of Psychological WellBeing and Keyes (1998) created The Social well-being scale. Theses scales include different number of items measuring (on a 5/7-point Likert scale, from 1 = strongly disagree to $5 / 7$ = strongly agree) the dimensions of well-being. These multi-item measures of well-being allowed researchers to examine the factor structure of different forms of overall well-being. According to Kozma et al. (1991), it is important to establish the construct validity of a measure by examining the extent to which the presumed components emerge in studies based on factor analysis. As stated in the literature "...the results obtained from earlier factor-analytic studies (Ryff, 1989; Ryff and Keyes, 1995) are marred by methodological problems. Particular problems include: low internal consistency and test-retest reliability of some scale used for assessing well-being as a multidimensional construct" (Kozma et al., 1991, p.7).

\section{The current study}

Based on the above mentioned theoretical assumptions and on an integration of Diener's (1985), Seligman's (2002), Ryff's (1995) and Keyes' (1998) models of wellbeing, the Psychosocial Well-Being Inventory (PSWBI) was developed. Its aim is to 
evaluate psychosocial well-being as a multidimensional construct that includes subjective, psychological and social components (dimensions) as related but distinct aspects of individuals' positive psychological functioning in their environment.

The study reported here describes the validation of this new instrument. The first aim of this study is to therefore establish the psychometric properties of this new instrument. The second aim of the study is to clarify the relationship between the PSWBI and other measures of well-being such as the Satisfaction with Life Scale/LSI, Subjective Happiness Scale /SH, Subjective Vitality Scale /SV, and Personal Growth Initiative Scale/PGI.

This paper reports only the findings from the validation study ( $n=449)$, with necessary references to the pilot study $(n=150)$ conducted before this validation study. Specifically, the content, construct, criterion, convergent and divergent validity of the PSWBI will be examined along with its reliability.

Method

Participants

Participants in the pilot and validation studies were recruited from the first, second and third years of study from the faculty of Psychology and Educational Sciences, University of Bucharest, Romania. The studies were based on convenience sampling but the samples were reasonably representative for the university students' population from which they were drawn.

Participants in the validation study were 449 students (155 males and 294 females), ages ranging from 18 to 40 years $(M=23.47, S D=5.68)$, studying at the Faculty of Psychology and Educational Sciences, University of Bucharest, Romania.

Procedure

Data collection for the validation study took place throughout the end of first semester of academic years 2008/2009 and 2009/2010.

Students enrolled in the educational psychology course were asked if they were willing to participate in the study, and a battery of surveys was distributed to those who volunteered. The purpose of the questionnaires was explained and completed questionnaires were handed in directly to the researcher. 
Measures

As part of the validation of the Psychosocial Well-Being Inventory, adjacent to this instrument, habitually measures of individuals' perception of well functioning in personal life and in social world were included.

The instruments administered to all participants were self-report, paper and pencil questionnaires and were translated into Romanian and then translated back into English with small language adaptations. Responses to all scales were rated on a Likert scale from 1 = strongly disagree to 5 = strongly agree. Item scores were summed to obtain total scale score. Reliability and validity evidence has been evaluated for each of these instruments. Therefore, in order to evaluate various aspects of students' psychological and social functioning and to compare measures with the PSWBI, the following instruments were used:

Satisfaction with Life Scale (Diener, Emmons, Larsen \& Griffin, 1985) was used to assess satisfaction with students' life as a whole. The scale consists of five items (Example: "I am satisfied with my life").

Self-Esteem (Rosenberg) Scale (Rosenberg, 1965) consisting of ten items (5 are reverse scored) was used for measurement of students' positive evaluation of themselves (Example: "On the whole, I am satisfied with myself").

Subjective Happiness Scale (Lyubomirsky and Lepper, 1999) is a four-item scale of global subjective happiness. Two items ask respondents to characterize themselves using both absolute ratings and ratings relative to peers, whereas the other two items offer brief descriptions of happy and unhappy individuals (Example: "In general, I consider myself: from to "not a very happy" to "very happy person").

Subjective Vitality Scale (for individual differences version) (Ryan and Frederick, 1997) with six items, was used for measurement of subjective vitality (that refers to the state of feeling alive and alert, and having energy and is considered an aspect of eudaimonic well-being as being vital and energetic is part of what it means to be fully functioning and psychologically well) (Ryan \& Deci, 2001) (Example of items: "I feel alive and vital").

Personal Growth Initiative Scale (Robitschek, 1998) was used for evaluation of the student's active and intentional involvement in changing and developing as a person. It was previously established (Robitschek \& Kashubeck, 1999; Whittaker \& Robitschek, 2001) that the PGIS is strongly positively related to psychological well- 
being and negatively related to psychological distress. The PGIS consists of nine items (Example: "I know how to change specific things that I want to change in my life").

The Attitudes Toward Self Scale (ATS) (Carver et al., 1988) was used to evaluate students' vulnerabilities to depression. ATS was designed to measure three potential self-regulatory vulnerabilities to depression: a) the holding of overly high standards, b) the tendency to be self-critical in case of failure, and c) the tendency to generalize from a single failure to the broader sense of self-worth. Consistently, only generalization was uniquely related to depression (Carver, 1998, Carver et al. 1999) (Example of item for 1) High Standards - "Compared to other people, I expect a lot from myself"; 2) Self-Criticism - "I get unhappy with anything less than what I expected of myself"; 3) Generalization from a single failure to the broader sense of self-worth - "If I notice one fault of mine, it makes me think about my other faults").

Psychosocial Well-Being Inventory was elaborated and developed based on Diener's (1984), Seligman (2002, 2005), Ryff's (1989, 2005) and Keyes (1998, 2003, 2005) models of subjective, psychological and social well-being. Participants were asked to rate how frequently during the past month they experienced three symptoms of subjective well-being related to everyday events (satisfaction, happiness and interest), three symptoms of subjective well-being related to the faculty life (satisfaction, happiness and interest related to the faculty), six symptoms of psychological well-being (those identified by Ryffs's model), and five symptoms of social well-being (those identified by Keyes's model).

PSWBI' items were generated from a review of the subjective, psychological and social well-being literature. According to Keyes' procedure (2003) applied in his interesting study (Flourishing. Positive psychology and the life well-lived), only a single item (deemed most representative of construct) for each component of each of three dimensions of well-being was formulated.

Twenty items were selected and then tested in the pilot study (2007/2008, academic year). Before the completion of the instrument, a qualitative study (with focus groups) was conducted in order to capture participants' understanding of the items. The 20 items were then submitted to a principal components analysis, which confirmed the four factor component structure of the questionnaire. Reliability analysis (in the pilot study) of the four factors using the leave-one-out procedure suggested that the scales would be improved by discarding three items. The remaining 17 items yielded acceptable to excellent internal consistency ranging from .63 to .89. These 17 items became part of the PSWBI as used in the present validation study to measure students' 
psychosocial well-being. Items are summed for subscale scores and subscales are summed to obtain a total PSWBI score. Higher scores indicate higher psychosocial well-being.

Assumptions of adequate sample size, missing values, normality, linearity, outliers, singularity and multi-collinearity were assessed prior to analysis to determine the data's suitability for factor analysis. Literature specified that skewness and kurtosis values of 2.3 or below are not problematic for confirmatory factor analyses and other types of structural equation models (Tabachnik \& Fidell, 2007). Absolute skewness and kurtosis values for the PSWBI items were all below 2. Several multivariate outliers were detected. Comparative analyses with and without outliers was made and the final decision was to keep them since they did not really influence the covariance matrix.

\section{Results}

Descriptive Results

The descriptive analyses of the scores obtained for the scales are reported in Table 1. The descriptive results of the pilot study were similar.

Table 1. Internal consistency (Cronbach Alpha Reliability), means and standard deviation for each PSWBI scale and for other measures

\begin{tabular}{|l|c|c|c|c|}
\hline \multicolumn{1}{|c|}{ Scale } & $\begin{array}{l}\text { No. of } \\
\text { items }\end{array}$ & $\begin{array}{l}\text { Alpha } \\
\text { reliability }\end{array}$ & Mean & SD \\
\hline $\begin{array}{l}\text { Subjective well - being related to everyday } \\
\text { events }\end{array}$ & 3 & .724 & 3.86 & .692 \\
\hline $\begin{array}{l}\text { Subjective well - being related to the faculty } \\
\text { events }\end{array}$ & 3 & .786 & 3.49 & .799 \\
\hline Psychological Well-Being & 8 & .843 & 3.80 & .726 \\
\hline Social Well-Being & 3 & .808 & 2.32 & .971 \\
\hline Psychosocial Well-Being & 17 & .880 & 3.38 & .600 \\
\hline Satisfaction with Life & 5 & .842 & 3.25 & .817 \\
\hline Self-Esteem (Rosenberg) & 10 & .890 & 3.95 & .698 \\
\hline Subjective Happiness & 4 & .821 & 3.37 & .543 \\
\hline Subjective Vitality & 6 & .651 & 3.55 & .834 \\
\hline Personal Growth Initiative & 7 & .879 & 3.73 & .643 \\
\hline Vulnerability to depression & & .604 & 3.23 & .641 \\
\hline
\end{tabular}


Principal component analysis

To examine whether the four underlying components of the PSWBI were perceived by the respondents as distinctive constructs, data have been subjected to an exploratory principal components factor analysis with Varimax rotation.

A Kaiser-Meyer-Olkin (KMO) analysis supported factorability, $R=.88$ and Bartlett's test indicated a breach of sphericity, $X^{2}=3035.049, d f=136, p=<.001$. However, factor analysis is robust to breaches of sphericity especially when the sample size is large (Tabachnik \& Fidell, 2007). A Cattell scree plot and Kaiser's criterion identified a four-factor solution that explained $61.31 \%$ of variance in scores.

Principal component analysis generally supported the hypothesised four-factor structure of the PSWBI, with psychological well-being (factor 1), subjective well-being related to everyday events (factor 2), social well-being (factor 3 ), and subjective wellbeing related to faculty events (factor 4 ).

Tabel 2. Psychosocial well-being's components and items loading in each factor

\begin{tabular}{|l|l|l|}
\hline Factors & No. of items, loading & Variance explained \\
\hline $\begin{array}{l}\text { Factor 1 } \\
\text { Psychological well-being }\end{array}$ & $\begin{array}{l}8 \text { items, } \\
\text { loading from .42 to } \\
.60\end{array}$ & $\begin{array}{l}36.780 \% \text { of } \\
\text { variance }\end{array}$ \\
\hline $\begin{array}{l}\text { Factor } 2 \\
\text { Subjective well-being related } \\
\text { to everyday event }\end{array}$ & $\begin{array}{l}3 \text { items } \\
\text { loading from .42 to } \\
0.80\end{array}$ & $\begin{array}{l}9.522 \% \text { of } \\
\text { variance }\end{array}$ \\
\hline $\begin{array}{l}\text { Factor 3 } \\
\text { Social well-being }\end{array}$ & $\begin{array}{l}3 \text { items } \\
\text { loading, from .62 to } \\
0.77\end{array}$ & $8.534 \%$ of variance \\
\hline $\begin{array}{l}\text { Factor 4 } \\
\text { Subjective well-being related } \\
\text { to the faculty events }\end{array}$ & $\begin{array}{l}3 \text { items } \\
\text { loading, from .69 to } \\
.80\end{array}$ & $6.483 \%$ of variance \\
\hline \multicolumn{2}{l}{\begin{tabular}{l} 
Cumulative variance explained: $61.31 \%$. \\
\hline
\end{tabular}}
\end{tabular}

Factor analysis has been carried out by using principal component analysis for each subscale. Results show that each item of each scale is satisfactorily explained by one factor (explaining from $45.78 \%$ of variances - SWBfe to $63,32 \%$ - PWB). Consequently, the following four subscales of PSWBI can be described: 
Psychological well being scale (PWB) (8 items) reflects the six dimensions of psychological well-being identified by Ryff (1989) respectively a) self-acceptance; b) positive relationships with other people) c) autonomy; d) environmental mastery; e) purpose in life; f) personal growth and two of the five items of social well-being identified by Keyes (1998): 1. Social integration ("I am indeed part of a certain social group") and 2. Social contribution ("I can contribute with something significant to the life of the society").

Subjective well-being related to everyday events scale (SWBede) measures students' evaluations of their satisfaction with life, happiness and interest in general (3 items).

Social Well-Being Scale (SoWB) contains three items reflecting the three out of five dimensions of social well-being identified by Keyes (1998): a) social acceptance; b) social actualization; c) social coherence.

Subjective well-being related to the faculty events scale (SWBfe) measures students' evaluations of their satisfaction with life, happiness and interest for the university (3 items).

Reliability Analysis

The four subscales yielded acceptable to excellent internal consistency. Cronbach's alpha for the overall PSWBI scale and the PSWBI subscales were ranged from .72 to .88 (table 1). As indicated in Table 1, the highest alpha reliability was for the scale of psychological well-being (.84) and the lowest reliability for the subjective well-being related to everyday events scale (.72).

Correlation Analysis

In order to check the construct validity of the PSWBI, correlations between scales were determined. According to the multidimensional model of well-being, the correlation of each scale should be positive.

As we can see in table 3, the Pearson coefficients ranged from low (.31) to moderate (.64) indicating the fact that PSWBI scales measure different but related constructs. Psychological well-being scale was more highly correlated with Subjective well-being related to everyday events than with the Subjective well-being related to the faculty events. 
Table 3. Inter-scale Correlation for the PSWBI

\begin{tabular}{|l|l|l|l|l|}
\hline Scale & $\begin{array}{l}\text { Subjective } \\
\text { Well - Being } \\
\text { related to } \\
\text { everyday } \\
\text { events }\end{array}$ & $\begin{array}{l}\text { Subjective } \\
\text { Well-Being } \\
\text { related to } \\
\text { the faculty } \\
\text { events }\end{array}$ & $\begin{array}{l}\text { Psychologi } \\
\text { cal Well- } \\
\text { Being }\end{array}$ & $\begin{array}{l}\text { Social } \\
\text { Well- } \\
\text { Being }\end{array}$ \\
\hline $\begin{array}{l}\text { Subjective Well - Being } \\
\text { related to everyday events }\end{array}$ & 1 & .411 & .642 & .386 \\
\hline $\begin{array}{l}\text { Subjective Well-Being related } \\
\text { to the faculty events }\end{array}$ & .411 & 1 & .399 & .312 \\
\hline Psychological Well-Being & .642 & .399 & 1 & .510 \\
\hline Social Well-Being & .386 & .312 & .510 & 1 \\
\hline $\begin{array}{l}\text { Correlation is significant at the } 0.01 \text { level (2-tailed). } \\
\text { N= 449 }\end{array}$
\end{tabular}

In order to assess the construct and the criterion validity of the PSWBI, measures that comprise similar subscales were included in this study: Satisfaction with Life Scale/LSI, Subjective Happiness Scale /SH, Subjective Vitality Scale /SV, and Personal Growth Initiative Scale/PGI.

Subscales of the PSWBI (Subjective well-being related to everyday events/SWBede, Subjective well-being related to the faculty events/SWBfe. Psychological well-being and Social well-being) and the LSI, SH, SV, and PGI were submitted to bivariate correlational analysis.

Table 4. Correlation Coefficients for PSWBI and the LS, SE, SH, SV, and PGI

\begin{tabular}{|l|l|l|l|l|l|}
\hline & $\begin{array}{l}\text { Subjective } \\
\text { Well - Being } \\
\text { related to } \\
\text { every day' } \\
\text { events }\end{array}$ & $\begin{array}{l}\text { Subjective } \\
\text { Well-Being } \\
\text { related to } \\
\text { the faculty } \\
\text { events }\end{array}$ & $\begin{array}{l}\text { Psychological } \\
\text { Well Being }\end{array}$ & $\begin{array}{l}\text { Social Well } \\
\text { Being }\end{array}$ & PSWB \\
\hline $\begin{array}{l}\text { Satisfaction } \\
\text { with Life }\end{array}$ & .585 & .276 & .535 & .371 & .571 \\
\hline $\begin{array}{l}\text { Subjective } \\
\text { Happiness }\end{array}$ & .468 & .219 & .433 & .206 & .416 \\
\hline $\begin{array}{l}\text { Self-Esteem } \\
\text { (Rosenberg) }\end{array}$ & .527 & .233 & .551 & .196 & .470 \\
\hline Subjective & .590 & .315 & .565 & .317 & .568 \\
\hline
\end{tabular}




\begin{tabular}{|c|c|c|c|c|c|}
\hline \multicolumn{6}{|l|}{ Vitality } \\
\hline $\begin{array}{l}\text { Personal } \\
\text { Growth } \\
\text { Initiative }\end{array}$ & .489 & .300 & .600 & .299 & .532 \\
\hline \multicolumn{6}{|c|}{$\begin{array}{l}\text { Correlation is significant at the } 0.01 \text { level (2-tailed). } \\
\mathrm{N}=449\end{array}$} \\
\hline
\end{tabular}

As Table 4 shows, all subscales of PSWBI and the other measures were significantly correlated at $p=<.001$. The Pearson coefficients ranged from low (.23) to moderate (.60) indicating the fact that PSWBI scales shared a moderate positive relationship with the positive functioning in life scales. However, there were discrepancies in correlations of the same domain. For example, the Subjective well-being related to everyday events scale was more highly correlated with the LS, SE, SH, SV, and PGI than the Subjective Well-Being related to faculty events and Psychological WellBeing more highly than Social Well Being. Psychosocial Well-Being scale was more highly correlated with LS, SV and PGI than with SH scales. This suggests that the scales are measuring a similar general construct but they discriminate optimally between domains.

The Attitudes toward Self Scale (ATS) was used for divergent validity analysis of PSWBI. Two of his scales (indicating the vulnerability to depression) had a negative correlation with PSWBI scales as expected.

Table 5. Correlation Coefficients for PSWBI and the scales of Vulnerabilities to depression

\begin{tabular}{|l|l|l|l|l|l|}
\hline & $\begin{array}{l}\text { Subjective } \\
\text { Well - } \\
\text { Being } \\
\text { related to } \\
\text { everyday } \\
\text { events } \\
\text { Well- } \\
\text { Being } \\
\text { related to } \\
\text { faculty } \\
\text { events }\end{array}$ & $\begin{array}{l}\text { Subjective } \\
\text { Well-Being }\end{array}$ & $\begin{array}{l}\text { Psychological } \\
\text { Well- } \\
\text { Being }\end{array}$ & Social & PSWB \\
\hline $\begin{array}{l}\text { Self-Criticism (ATS) } \\
\text { a single failure to the } \\
\text { broader sense of } \\
\text { self-worth (ATS) }\end{array}$ & -.255 & $-.005 \mathrm{NS}$ & -.260 & -.150 & -.210 \\
\hline Vulnerabilities to &.- .249 & $.007 \mathrm{NS}$ & -.166 & $-.076 \mathrm{NS}$ & -.127 \\
\hline
\end{tabular}




\begin{tabular}{|l|l|l|l|l|}
\hline depression & & & & \\
\hline Correlation is significant at the 0.01 level (2-tailed). \\
$\mathrm{N}=449$
\end{tabular}

The results in table 5 show that the Pearson' coefficients are small but negative that suggests that the PSWBI measures an opposite construct compared to the ATS (vulnerabilities to depression scale).

To examine whether the scales used for evaluating students' perceptions of their functioning in life were perceived by the respondents as distinctive constructs, the data for all these scales (including the scores of the four components of PSWBI) were subjected to another principal components factor analysis with Varimax rotation.

Tabel 6. Perceptions of functioning in life's components and variance explained by each of the three factors

\begin{tabular}{|l|l|l|l|}
\hline Scale & $\begin{array}{l}\text { Factor 1 } \\
40,91 \% \text { of } \\
\text { variance } \\
\text { explained }\end{array}$ & $\begin{array}{l}\text { Factor 2 } \\
14,22 \% \text { of } \\
\text { variance } \\
\text { explained }\end{array}$ & $\begin{array}{l}\text { Factor 3 } \\
9,05 \% \text { of } \\
\text { variance } \\
\text { explained }\end{array}$ \\
\hline $\begin{array}{l}\text { Subjective Well-Being related to everyday } \\
\text { events }\end{array}$ & & .676 & \\
\hline $\begin{array}{l}\text { Subjective Well-Being related to faculty } \\
\text { events }\end{array}$ & & .655 & \\
\hline Psychological Well-Being & .558 & .657 & \\
\hline Social Well-Being & .669 & .737 & \\
\hline Satisfaction with Life & .629 & & \\
\hline Self-Esteem (Rosenberg) & .787 & & \\
\hline Subjective Happiness & .784 & & \\
\hline Subjective Vitality & & & \\
\hline High standard & & & \\
\hline Self criticism & & & \\
\hline Generalization & & & \\
\hline Cumulative variance explained: $64,42 \%$ & & \\
\hline
\end{tabular}

Principal component analysis yielded three-factor structure of these measures, with positive evaluation's scales (factor 1), well-being scales (factor 2), and vulnerability to depression subscales (factor 3). 
Factor 1 comprises (as is shown in table 6) satisfaction with life, self-esteem, subjective happiness, subjective vitality, and high standard. Factor 2 comprises the dimensions of psychosocial well-being and factor 3, the scores of vulnerabilities to depression (self criticism and generalization from a single failure to the broader sense of selfworth). Correlations between factors are ranged from .65 to .68. These results confirm that PSWBI scales are measuring a distinct construct from the constructs measured by the other scales.

\section{Discussion}

This study had two objectives. The first objective was to establish the psychometric proprieties of PSWBI and the second was the clarification of the relationship between the PSWBI and other measures of well-being such as the Satisfaction with Life Scale/LSI, Subjective Happiness Scale /SH, Subjective Vitality Scale /SV, and Personal Growth Initiative Scale/PGI.

The PSWBI was expected to have acceptable psychometric properties, content, criterion, convergent and divergent validity.

The PSWBI demonstrated a good reliability using Cronbach's alpha for the overall PSWBI scale and for the four PSWBI's subscales. The internal consistency of the PSWBI' total and subscales' scores was good (all alphas were above .70). This indicates that the PSWBI is a reliable measure for students' well-being.

It was predicted that the PSWBI would demonstrate construct validity in the factor analysis. Performing factor analytic procedures on the 17 items of the PSWBI has produced a four-factor solution with scale-specific items loading their respective factors. The four factors (Subjective well-being related to every day's event/SWBede, Subjective well-being related to the faculty events/SWBfe. Psychological well-being and Social well-being) were extracted and accounted for a significant proportion of variance with adequate goodness-of-fit for the model obtained.

The PSWBI demonstrated good convergent and divergent validity when assessed against Satisfaction with Life Scale/LSI, Subjective Happiness Scale /SH, Subjective Vitality Scale /SV, Personal Growth Initiative Scale/PGI, and The Attitudes toward Self Scale (ATS). The PSWBI showed acceptable correlations with Satisfaction with Life Scale/LSI, Subjective Happiness/SH, Subjective Vitality/SV, and Personal Growth Initiative Scale/PGI indicating that the PSWBI measurement of well-being is in alignment with that of these previously validated scales. The Attitudes toward Self 
Scale (ATS) scale was used for divergent validity analysis and had a negative correlation as expected. Correlations between the subscales of the PSWBI and the other scales showed a moderate relationship between the constructs, supporting the conclusion that the PSWBI is a valid measure of well-being in that it can be used to predict scores about a separate and yet related construct.

These results support previous evidence that well-being is best conceived as a multidimensional phenomenon that includes aspects of both the hedonic and eudaimonic conceptions of well-being (Diener, 1984, 2005; Ryff, 1989; Keyes, 1998, 2003, 2005). Studies analysing diverse set of wellness indicators generally reported two factors (one reflecting happiness and another reflecting meaningfulness and personal meaning). These two factors were themselves moderately correlated (King and Napa, 1998). These findings indicate that the hedonic and eudaimonic approaches to good life are distinct but complementary. In the eudaimonic approach, meaningfulness and personal meaning were approached more frequent as far as the individual's self is concerned. The results from present factorial analysis of the scores referring to students' psychosocial well-being pointed out that social experience is added to the personal meaning of the individual, especially in collectivistic cultures (Hall, 1966; Trimbitas et al., 2007; Ciochina, Faria, 2009). As shown, students' perceptions of their social integration and of their social contribution support their psychological well-being and not their social well-being as in Keyes' model of social well-being. These appear to be in line with other findings (Linley, et al., 2009; Roysamb, 2006; Kwan, et al., 1997).

Considering the results of the present study, some weak points (limitations) of this study should be kept in mind before generalizing. One possible limit comes from investigating subjects belonging to a single category of students (psychology students). Second, participants did not complete the questionnaire in a controlled environment and not all participants completed the questionnaire in the same context. Further to this, considering the large age range of students, differences may have been present in regards to their life experience. The results of this study are limited to its particular context given that students' subjective well-being may be affected by several factors related to faculty dimensions themselves, including learning environments, curriculum, and teaching methods. Further, the stability of the PSWBI is unclear as no test-retest analysis was performed. A major drawback of this research is given by the recognized limitations of self-report scales, which rely exclusively on people's cognitive labels of their emotions. Future research should seek to tap alternative sources of information beyond self-report. It is strongly suggested that more research be conducted in this area to gain a comprehensive understanding of the students' well being. The PSWBI should be submitted to further 
statistical analysis in order to establish it as a stable measure of students' psychosocial well-being.

The main practical implication of the validation of the PSWBI is the fact that it will provide a special-designed measure for the dimensions of well-being among Romanian university students. The instrument supports the idea that the level of wellbeing cannot be measured using only one score; rather, a profile composed of at least four separate scores is required to provide more comprehensive information about individuals' well-being. Data collected with this instrument may help to build student's psychosocial well-being profiles that could highlight the areas in need of improvement in order to promote well-being in the academic environment.

\section{References}

Andrews, F. M. \& Withey, S. B. (1976). Social Indicators of Well-Being: American's Perceptions of Life Quality. New York: Plenum Press.

Andrews, F. M., Robinson, J. P. (1991). Measures of Subjective Well-Being, In J. P. Robinson, P. Shaver, L. Wrightsman (Eds.), Measures of Social Psychological Attitudes (Vol. I, pp. 61 - 114). San Diego, CA: Academic Press.

Bradburn, N. M. (1969). The Structure of Psychological Well-being. Chicago: Aldine.

Carver CS, Scheier MF. (1999). Themes and issues in the self-regulation of behavior. In R.S. Wyer Jr (Ed.) Perspectives on Behavioral Self-Regulation: Advances in Social Cognition, XII:1-105. Mahwah, NJ: Erlbaum.

Carver, C. S. (1998). Generalization, adverse events, and development of depressive symptoms. Journal of Personality, 66, 609-620.

Cicognani, E., Pirini, C., Keyes, C.L., Joshanloo, M., Rostami, R. , Nosratabadi, M. (2008). Social Participation, Sense of Community and Social Well Being: A Study on American, Italian and Iranian University Students. Social Indicators Research. 89:97-112

Ciochină, L., Faria, L. (2009). Individualism and Collectivism: What Differences between Portuguese and Romanian Adolescents? The Spanish Journal of Psychology, 12 (2), 555564

Csikszentmihalyi, M. (1975). Beyond boredom and anxiety. San Francisco: Jossey-Bass. 
Csikszentmihalyi, M. (1990). Flow: The psychology of optimal experience. New York: Harper \& Row.

Csikszentmihalyi, M. (1997). Finding flow: The psychology of engagement with everyday life. New York: Basic Books.

Diener, E. (1984). Subjective well-being, Psychological Bulletin, 95, 542- 575.

Diener, E., Emmons, R.A., Larsen, R.J., \& Griffin, S. (1985). The Satisfaction with Life Scale. Journal of Personality Assessment, 49, 1-5.

Diener, E., Lucas R.E., Osihi S. (2005). Subjective well-being. The science of happiness and life satisfaction. In Snyder, C.R., Lopez, S.J. (Eds.), Handbook of Positive Psychology (pp. 63 - 71). Oxford: University Press.

Hall, E. (1976). Beyond Culture. Garden City, NY: Doubleday.

Haynes, N.M. (2002). Addressing students' social and emotional needs: The role of mental health teams in schools. Journal of Health \& Social Policy, 16(1-2), 109-123.

Kafka, G.J., Kozma, A. (2002). The construct validity of Ryff's scales of psychological well-being (SPWB) and their relationship to measures of subjective well-being. Social Indicators Research, 57(2), 171 - 179.

Keyes, C. L. M. (1998). Social well being. Social Psychology Quarterly, 61 (2), 121-140.

Keyes, C. L. M. (2003). Complete mental health: An agenda for the 21 th century. In C. L. M. Keyes \& J. Haidt (Eds.), Flourishing. Positive psychology and the life well-lived (pp. 293312). Washington DC: American Psychological Association Press.

Keyes, C.L.M, Lopez, S.J (2005). Toward a Science of Mental Health. Positive direction in diagnosis and intervention. In , C.R. Snyder, S.J. Lopez (Ed.), Handbook of Positive Psychology (pp .45-59). Oxford: University Press

King, L.A., C.K. Napa, C.K (1998). What makes a life good? Journal of Personality and Social Psychology, 75, 156-165.

Kozma, A., Stones, M.J., McNeil, J.K. (1991). Psychological Well-Being in Later Life. Toronto: Butterworths. 
Kwan, V. S. Y, Bond, M. H., \& Singelis, T. M. (1997). Pancultural explanations for life satisfaction: Adding relationship harmony to self-esteem. Journal of Personality and Social Psychology, 73, 1038-1051.

Linley, P.A., Maltby, J., Wood, A.M., Osborne, G., Hurling, R. (2009). Measuring happiness: The higher order factor structure of subjective and psychological well-being measures. Personality and Individual Differences, 47 (8), 878-884

Lyubomirsky, S., \& Lepper, H. S. (1999). A measure of subjective happiness: Preliminary reliability and construct validation. Social Indicators Research, 46, 137-155.

Lyubomirsky, S. (2001). Why are some people happier than others?: The role of cognitive and motivational processes in well-being. American Psychologist, 56, 239-249.

Misra, R., McKean, M. (2000). College students' academic stress and its relation to their anxiety, time management, and leisure satisfaction. American Journal of Health Studies, $16(1), 41-51$.

Negovan, V. (2007). The psychodynamics of subjective well being related to university students' involvement in volunteering activities. In M. Anitei, M. Popa, C. L. Mincu, A.M. Pap (Eds.). Proceedings of the Centenary of Psychology at the University of Bucharest (pp. 1055 - 1069). Bucharest: Editura Universitatii.

Pavrot, W., \& Diener, E. (1993). Review of the Satisfaction with Life Scale. Psychological Assessment, 5, 164-172.

Robitschek, C. (1998). Personal growth initiative: The construct and its measure. Measurement and Evaluation in Counselling and Development, 30, 183-198.

Robitschek, C., \& Kashubeck, S. (1999). A structural model of parental alcoholism, family functioning, and psychological health: The mediating effects of hardiness and personal growth orientation. Journal of Counseling Psychology, 46, 159-172.

Rosenberg, M. (1965). Society and the adolescent self-image. Princeton, NJ: Princeton University Press.

Ross, S., Cleland, J., \& Macleod, M.J. (2006).Stress, debt and undergraduate medical school performance. Medical Education, 40, 584 - 489.

Roysamb, E. (2006), Personality and Well-Being, In Volrath, Margarete (Ed.), Handbook of Personality and Health (pp. 115 - 134). England: John Wiley \&Sons Ltd. 
Ryan R. M. Deci, and E. L. (2000), The Darker and Brighter Sides of Human Existence: Basic Psychological Needs as a Unifying Concept, Psychological Inquiry, Vol. 11, No. 4, 319-338.

Ryan, R. M., \& Deci, E. L. (2001). On happiness and human potentials: A review of research on hedonic and eudaimonic well-being. In S. Fiske (Ed.), Annual review of psychology, 52, 141-166.

Ryan, R. M., \& Frederick, C. M. (1997). On energy, personality and health: Subjective vitality as a dynamic reflection of well-being. Journal of Personality, 65, 529-565.

Ryff, C. D. (1989). Happiness is everything, or is it? Explorations on the meaning of psychological well-being. Journal of Personality and Social Psychology, 57, 1069-1081.

Ryff, C. D., Keyes, C. L. M. (1995). The structure of psychological well-being revisited. Journal of Personality and Social Psychology, 69, 719-727.

Ryff, C., Singer, B. (2005). Integrative science in pursuit of Human Health and Well-being. In Snyder, C.R., Lopez, S.J. (Eds.), Handbook of Positive Psychology (pp. 541 - 555). Oxford: University Press.

Seligman, M. E. P. (2002). Authentic happiness. New York: Free Press.

Seligman, M. E. P., Parks, A.C., Steen, Tracy (2005). A balanced psychology and a full life. In Huppert, A. Felicia, Baylis, N., Keverne, B. (Eds.), The science of well-being (pp. 275 284). Oxford: University Press.

Sheu Hung-Bin, Lent, R.W. (2009). A social cognitive perspective on well-being in educational and work settings: Cross-cultural considerations. International Journal for Educational and Vocational Guidance, 9, 45-60.

Tabachnick, B.G., Fidell, L.S. (2007). Using multivariate statistics. (5 $5^{\text {th }}$ ed.) Boston: Pearson Education.

Trimbitas, O., Yang Lin, Clark, D. (2007). Arta de a cere scuze in cultura romaneasca: Use of Apology in Ethnic Romanian Culture. Human Communication. A Publication of the Pacific and Asian Communication Association, 10 (4), pp. 421 - 436.

Verger, P., Combes, J - B., Kovess-Masfety, V., Choquet, M., Guagliardo, V., Rouillon, F., Peretti-Wattel, P. (2009). Psychological distress in first year university students: socioeconomic and academic stressors, mastery and social support in young men and women. Social Psychiatry and Psychiatric Epidemiology, 44 (8), 643 - 650. 
Whittaker, A. E., \& Robitschek, C. (2001). Multidimensional family functioning as predictors of personal growth initiative. Journal of Counseling Psychology, 48, 420-427.

About the author:

Dr. Valeria Negovan is a Senior Lecturer at the University of Bucharest, the Faculty of Psychology and Educational Sciences, Psychology Department, teaching courses of Educational Psychology, Learning Psychology (undergraduate level), Career Psychology, Advanced Educational Psychology and Crisis Management in Schools (M.Sc. level). Her scientific research activity focuses on research areas such as learning strategies, autonomy and self-regulation, adaptation and coping strategies in academic environment, the role of values in career development, university students' well-being.

Address for correspondence: negovan_v@yahoo.com 